\title{
EFFECT OF OPERATING CONDITIONS ON THE LIQUID WATER CONTENT FLOWING OUT OF THE CATHODE SIDE AND THE STABILITY OF PEM FUEL CELL PERFORMANCE
}

\author{
Mulyazmi ${ }^{1^{*}}$, Wan R.W. Daud ${ }^{2}$, Elly D. Rahman ${ }^{1}$, Purwantika ${ }^{1}$, Putri A. Mulya ${ }^{1}$, \\ Nia G. Sari ${ }^{1}$ \\ ${ }^{1}$ Department of Chemical Engineering, University of Bung Hatta Padang, Padang, West Sumatera \\ 25586, Indonesia \\ ${ }^{2}$ Fuel Cell Institute, University Kebangsaan Malaysia, 43600 UKM Bangi, Selangor, Darul Ehsan, \\ Malaysia
}

(Received: July 2018 / Revised: October 2018 / Accepted: April 2019)

\begin{abstract}
Management of the water in the stack is a major problem in achieving optimal performance of a Proton Exchange Membrane (PEM) fuel cell. One of the problems caused by water imbalance in the PEM system is the formation of liquid water on the side of the cathode. High water content in the PEM fuel cell stack causes liquid water and flooding, and decreases its performance. The presence of liquid water on the cathode side of the fuel cell leads to a decrease in the amount of oxygen reacting in the catalyst layer. The results of this study indicate that a general increase in water content results in a decrease in the performance of PEM fuel cell systems. The highest water content occurs at a current density of 0.9 , with Rha and RHc of $90 \%$. In this condition, system performance is relatively stable at 0.67 volts, with $0.00016 \mathrm{gr} / \mathrm{cm}^{2}$ of liquid water content produced. Above this water content, system performance decreases significantly.
\end{abstract}

Keywords: Liquid water; Performance; Proton exchange membrane; Relative humidity

\section{INTRODUCTION}

Development of the design system process to improve the performance of PEM systems is currently still being undertaken. The aim is to obtain good fuel cell stack durability and high system efficiency (Kaluža et al., 2015). A single cell PEM fuel cell in the form of an Electrolyte Membrane Assembly (MEA) is arranged like a sandwich between two bipolar plates. The MEA consists of two electrodes; the anode and cathode are separated by a proton conducting membrane. In the anodic membrane interface, hydrogen is oxidized and the resulting protons are transported through the membrane. In the cathode interface, oxygen is reduced and then produces water, which flows out through the gas flow channel. Systems on stack PEM fuel cells are formed and arranged from many single cells that create a balanced operating system.

The balance of the amount of water content in the system is one of the most important factors that always needs to be controlled in the PEM fuel cell. The purpose is to ensure the membranes in the stack are always hydrated. The membrane system on the stack fuel cell will be dry and cracked if the water content is very low. Furthermore, if the water content is too high in the fuel cell system, condensation and flooding will occur on the cathode side (Falcão et al., 2009).

*Corresponding author's email: mulyazmi@yahoo.com, Tel. +62-81374082943

Permalink/DOI: https://doi.org/10.14716/ijtech.v10i3.2929 
Situation related to the transfer of water content in the system are include electro-osmotic drag (EOD) from the anode to the cathode side; diffusion of water back from the cathode to the anode side; and a process of liquid water formation on the anode and cathode side (Kraytsberg \& EinEli, 2006).

EOD is the transport of protons together with water molecules passing through the membrane from the anode to the cathode side in the stack fuel cell. Water that migrates with protons will join with the water generated by electrochemical reaction and accumulate on the cathode side. Back diffusion in the fuel cell system occurs if there is a gradient between the amounts of water from the anode to the cathode side. The presence of water in PEM fuel cells has good and bad effects. On one side of the water needed to ensure good conductivity of the membrane proton, but the other side of the water can block the flow of reactants moving to the surface of the catalyst to react. If the proton exchange membrane is dry, protons cannot migrate, so ionic conductivity is low (Guvelioglu \& Stenger, 2007). Another influence is blocking of the access of protons to the catalyst surface (Liu et al., 2006a; Liu et al., 2006b). Although flooding can occur on both sides of the electrode (anode and cathode) fuel cell system, floods that occur at the cathode can have a serious effect, because the oxygen reduction reaction can also produce water (Rao et al., 2007). At a low current density, back diffusion is more dominant than electro-osmotic drag (EOD) in the fuel cell stack. Conversely, if current density increases, the EOD will become dominant. As a result, hydration takes place in the anode, while the cathode side will be flooded. Protons cannot migrate if the membrane dries under conditions that cause low ionic conductivity values.

Water content in the system can have several effects: it can affect the transport of protons to the surface of the catalyst; and increase the value of activation polarization because the reactivity value produced by the fuel cell system is lower (Stumper et al., 2005). In contrast, the amount of water in many flow field channels and on the electrode gas pores will cause decreased activation of the catalyst. If there is a large amount of water in the stack, flooding can occur, which decreases system performance. Generally, floods in fuel cell stacks will affect the resulting current density, while removing the water content from the flow field depends on the interaction and operating conditions (Sun et al., 2007). Flooding occurs as a result of a low current density value caused by certain operating conditions, such as low temperatures, humidity levels and gas flow rates, meaning the gas phase saturates more rapidly with water vapor (Spernjak et al., 2007). Although flooding can occur at the electrodes on the anode and the cathode sides of the fuel cell system, that which takes place at the cathode is crucial, as there is an oxygen reduction reaction that can also produce water (Rao et al., 2007). Amirinejad et al. (2006) conducted research on the optimal operating system conditions that occur at the highest pressure, showing that the pressure on the cathode side had more influence on the performance of PEM fuel cells. Park and Caton (2008) conducted research on the influence of humidity on the cathode. Their results indicate that it affects the EOD at low current densities and also affects the water content in the membrane, especially at the cathode. Increasing the current density, or decreasing the EOD coefficient, will increase the water supply to the anode side of the membrane. Yan et al. (2006) studied whether cell performance could be improved by increasing the concentration of gas flow into the cathode and its temperature and humidity. Li and Sabir (2005) studied a design capable of removing water by flowing gas through a channel, with no stagnant areas formed on the surface of the cathode as a result of the accumulation of water.

Previous research has focused on the effect of water balance on various phenomena in the fuel cell stack, and the operating conditions of the system to achieve optimal fuel cell system performance. Furthermore, it is necessary to study the effect of liquid water on the cathode side on the system performance achieved. The focus of this study is the influence of several operating 
conditions of the PEM fuel cell system on the formation of concentrations of liquid water flowing out from the cathode. Moreover, the study also aims to determine the effect of liquid water content flowing out the cathode side and its effect on system performance stability. The condition of this system is based on its water balance, which is influenced by several factors, such as the value of relative humidity at the anode (Rha) and the cathode (Rhc), and current density. The regulation of water balance settings can be predicted using a mathematical model.

\section{METHODOLOGY}

\subsection{Research Design}

Several methods are used to achieve the balance of water content in the PEM fuel cell stack. One approach to achieving sufficient water content is to use an external humidifier on the PEM fuel cell system, which is a type of membrane. The external humidifier function in this study is to make hydrogen humidity as a reactant before flowing into the anode side, and oxygen humidity before flowing to the cathode side (Li \& Lv, 2018). The components flowing out from the side of the anode are reused as reactants and supplied to the anode. Water vapor that flows out from the cathode side is used again for hydrogen humidity as a reactant before flowing into the anode side, and air humidity before flowing into the cathode side. The design of this study is based on research conducted by Mulyazmi et al. (2013); the research scheme is shown in Figure 1. Mulyazmi et al. studied the factors that influence the balance of the amount of water in PEM fuel cells by varying the operating conditions of the system, such as flow rate and the humidity of the reactants flowing into the anode and cathode, system temperature, water transport in electroosmotic drag, the amount of water diffused from the cathode to the anode side, and the formation of water condensation on the anode and cathode sides. Mulyazmi et al. $(2017 ; 2018)$ conducted a studies of the influence of operating conditions (relative humidity, temperature, stoichiometric ratio and pressure) on the performance of the PEMFC system. Their results show that optimal system performance occurs between $70 \%$ and $90 \%$ Rhc and $70 \%$ Rha.

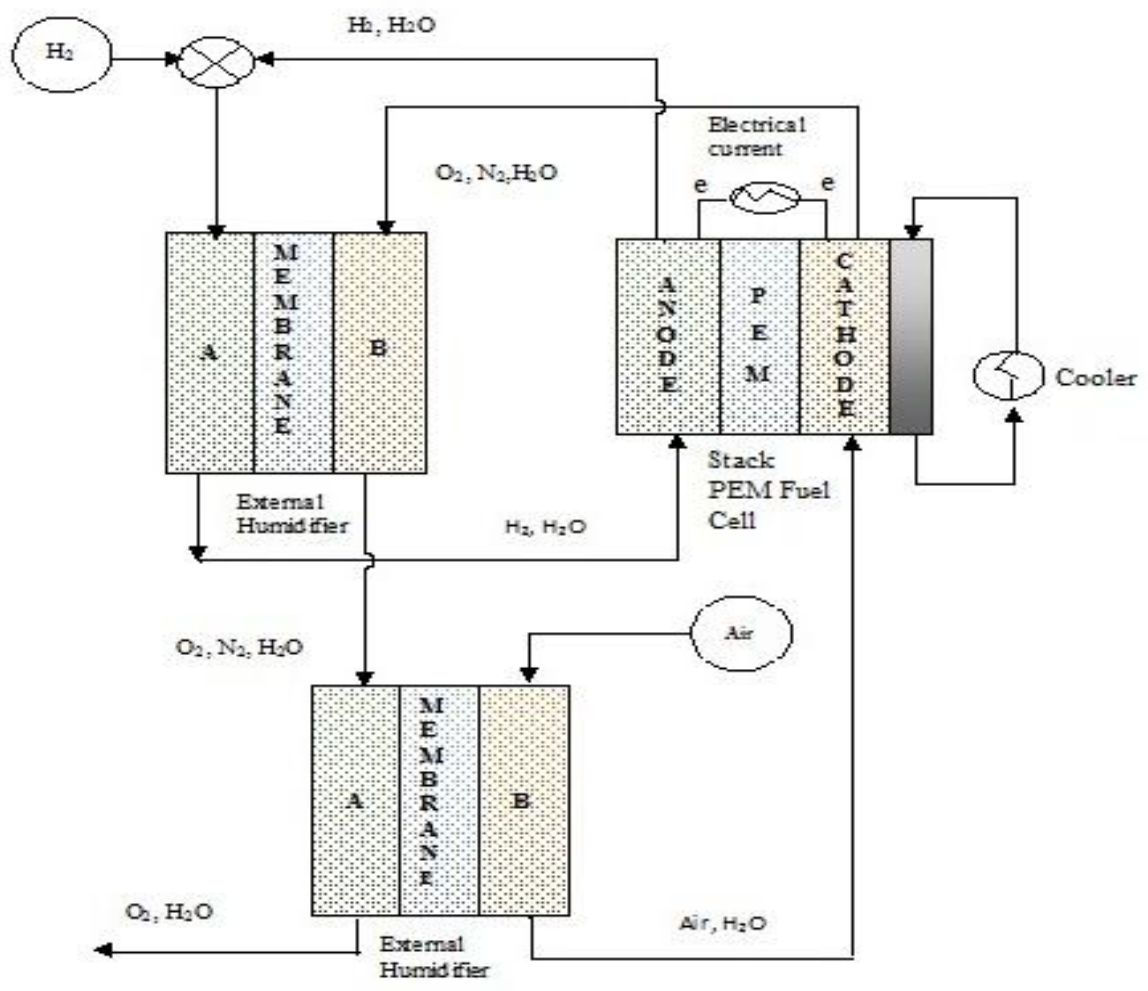

Figure 1 Design of the PEM fuel cell system process 
The purpose of this study is to determine the effect of system operating conditions on the amount of maximum water content flowing out from the cathode side, and to determine the effect of water content on system performance stability.

The amount of membrane water content is influenced by several factors, including the relative humidity of hydrogen at the anode, the relative humidity of oxygen at the cathode side, and the level of current density. The operating parameters of the study are shown in Table 1.

Table 1 Operating parameters in the PEM fuel cell system

\begin{tabular}{ll}
\hline \multicolumn{1}{c}{ Parameter } & \multicolumn{1}{c}{ Value } \\
\hline Relative humidity on the anode side (Rha) & $50 \%$ to $90 \%$ \\
Relative humidity on the cathode side (Rhc) & $75 \%$ and $90 \%$ \\
Thick dry membrane & $0.0051 \mathrm{~cm}$ for Nafion $112_{\text {Catalyst load }} 0.0002 \mathrm{~g} \mathrm{~cm}^{-2}$ \\
Thick catalyst & $0.0005 \mathrm{~cm}$ \\
Pressure on the anode and cathode sides & $1 \mathrm{~atm}$ \\
Stoichiometric ratio for hydrogen & 1.2 \\
Stoichiometric ratio for oxygen & 2 \\
Current density & 0.50 .7 and $0.9 \mathrm{~A} / \mathrm{cm}^{2}$ \\
\hline
\end{tabular}

\subsection{Mathematical Model}

The principle for determining the concentration of reactants flowing into PEM fuel cells has been described by Mulyazmi et al. (2013). The model can be used to determine the concentration related to system design. The amount of liquid water that flows out of the PEM fuel cell includes the water which flows into the fuel cell stack and that from the reaction results in the system. Based on the calculation of the material mass balance by (Mulyazmi et al., 2018) the concentration of water vapor dissolved in hydrogen that flows $\mathcal{N}_{\mathrm{H}_{2} \mathrm{O} \text { in } \mathrm{H}_{2}}$ in the anode side is defined as follows:

$$
\mathcal{N}_{\mathrm{H}_{2} \mathrm{O} \text { in } \mathrm{H}_{2}}=\mathcal{S}_{\mathrm{H}_{2}} \cdot \mathcal{N}_{\mathrm{H}_{2}} \cdot \eta_{\text {cell }} \cdot \frac{\varphi \cdot P_{V_{S}}}{P_{a}-\varphi \cdot P_{V_{S}}}
$$

where $\mathcal{S}_{H_{2}}$ is the stoichiometry of hydrogen; $\mathcal{N}_{\mathrm{H}_{2}}$ the concentration of hydrogen (mol s${ }^{-1}$ ); $\eta_{\text {cell }}$ the number of cells; $\varphi$ relative humidity; $P_{a}$ pressure on the anode side (atm); and $P_{V_{S}}$ saturated vapor pressure (atm).

The concentration of water vapor dissolved in oxygen flowing into the cathode side is:

$$
\mathcal{N}_{\mathrm{H}_{2} \mathrm{O} \text { in } \mathrm{O}_{2}}=\frac{\mathcal{S}_{\mathrm{O}_{2}} \cdot}{4 F} i \cdot \eta_{\text {cell }} \frac{\varphi \cdot P_{V_{S}}}{P_{a}-\varphi \cdot P_{V_{S}}}
$$

where $\mathcal{S}_{\mathrm{O}_{2}}$ is the stoichiometry of oxygen; $F$ the Faraday constant; and $i$ the current density value $\left(\mathrm{A} \mathrm{cm}^{-2}\right)$.

Water in the liquid phase on both sides of the fuel cell stack occurs when the relative humidity is above $100 \%$.

$$
\mathcal{N}_{\mathrm{H}_{2} \mathrm{O} \text { in } \mathrm{H}_{2} \text { out }}=\mathcal{N}_{\mathrm{H}_{2} \text { un reac }} \cdot \eta_{\text {cell }} \cdot \frac{P_{\text {sat }}}{P-. P_{\text {sat }}}
$$

where $\mathcal{N}_{H_{2}}$ un reac is hydrogen that does not react on the anode side (mol); $P_{\text {sat }}$ is the saturated vapor pressure (atm); and $P$ is total pressure (atm). 
The concentration of water vapor in oxygen at a relative humidity is $100 \%$ is as follows:

$$
\mathcal{N}_{\mathrm{H}_{2} \mathrm{O} \text { in air,out }}=\mathcal{N}_{\text {air,out }} \eta_{\text {cell }} \frac{P_{\text {sat }}}{P-. P_{\text {sat }}}
$$

where $\mathcal{N}_{\text {air,out }}$ is the concentration of oxygen out of the cathode side (mole); $\mathcal{N}_{\mathrm{H}_{2} \mathrm{O} \text { in } \mathrm{H}_{2, \text { out }}}$ is the water vapor flowing out of the anode side (mole); and $\mathcal{N}_{\mathrm{H}_{2} \mathrm{O} \text { in air, out }}$ is the water vapor flowing out of the cathode side (mole).

The number of protons that pass through the membrane from the anode to the cathode side in the EOD phenomenon $\mathcal{N}_{\text {drag }}$ can be calculated by the following equation (Yu et al., 2005; Zhou et al., 2006; Zong et al., 2006):

$$
\mathcal{N}_{\text {drag }}=\frac{n_{d}}{F} i
$$

where $n_{d}$ is the coefficient of EOD.

The coefficient of the EOD value $n_{d}$ is defined as follows:

$$
n_{d}=\frac{2.5 \lambda \text { pem }}{22}
$$

where $\lambda$ pem is the water content in the membrane.

The water content of the membrane in the fuel cell stack is:

$$
\lambda=0.0043+17.81 a_{H 2 O}-39.85 a_{H 2 O}^{2}+36 . a_{H 2 O}^{3} \quad 0<a_{H 2 O} \leq 1
$$

where $a_{H 2 O}$ is the water activity on the membrane.

The water activity on the membrane $a_{H 2 O}$ is calculated using the following equation:

$$
a_{H 2 O}=\frac{a_{H 2 O}, a+a_{H 2 O}, c}{2}
$$

$a_{H 2 O, a}$ is the water activity in the membrane on the fuel cell anode; and $a_{H 2 O, c}$ is the water activity in the membrane on the fuel cell cathode.

The amount of water that moves across the membrane from the cathode to the anode side of the fuel cell in the back diffusion phenomenon $\mathcal{N}_{\text {diff,H20 }}$ is defined by Zong et al. (2006), Gao et al. (2010) and Real (2007) as:

$$
\mathcal{N}_{\text {diff }, H 20}=D_{w} \frac{\left(C_{C, v-} C_{A, v}\right)}{x_{m}}
$$

$D_{w}$ is the diffusion coefficient on the fuel cell membrane; $C_{C, v}$, is the water content on the cathode side of the fuel cell (mol); $C_{A, v}$ is the water content on the anode side of the fuel cell (mol); and $x_{m}$ is the membrane thickness $(\mathrm{m})$.

Hassan et al. (2009) show that water diffuses from the anode to the cathode side as follows:

$$
J_{w}=k_{g}\left(y_{a}-y_{c}\right)
$$


$k_{g}$ is the mass transfer coefficient; $y_{a}$ is the molar moisture content at the anode; and $y_{c}$ is the molar moisture content at the cathode. The fuel cell system mass transfer coefficient is:

$$
\frac{1}{k g}=\frac{K}{k_{A}}+\frac{1}{k_{C}}
$$

$K$ is the moisture coefficient; $k_{A}$ is the condensation coefficient; and $k_{C}$ is the evaporation mass transfer coefficient. The water vapor flowing out of the anode side is as follows:

$$
\mathcal{N}_{\mathrm{H}_{2} \text { O out anode }}=\left(\mathcal{S}_{\mathrm{H}_{2}} \cdot \mathcal{N}_{\mathrm{H}_{2}} \cdot \eta_{\text {cell }} \cdot \frac{\varphi \cdot P_{V_{S}}}{P_{a}-\varphi \cdot P_{V_{S}}}-\frac{n_{d}(x) I(x)}{F}\right)+k_{g}\left(y_{a}-y_{c}\right)
$$

The concentration of water vapor flowing out of the cathode side is as follows:

$$
\begin{aligned}
\mathcal{N}_{\mathrm{H}_{2} \text { O out }, \text { cathode }} & \left(\mathcal{S}_{O_{2}} \cdot n_{\text {cell }} \frac{\mathcal{N}_{O_{2}}}{X O_{2}} \frac{\varphi \cdot P_{V_{s}}}{P_{c}-\varphi \cdot P_{V_{s}}}+\frac{\mathcal{N}_{H_{2} \text { supply }}}{\mathcal{S}_{H_{2}}}+\frac{n_{d}(x) I(x)}{F}\right) \\
& -k_{g}\left(y_{a}-y_{c}\right)
\end{aligned}
$$

\section{RESULTS AND DISCUSSION}

The formation of liquid water produced by PEM fuel cells affects the performance of the system. Optimal system performance is achieved using operating conditions such as pressure on the anode and cathode sides of $1 \mathrm{~atm}$; stoichiometric ratio of 1.4 for hydrogen and 2 for oxygen; and Rha from $50 \%$ to $90 \%$. Water vapor is formed if the value of relative humidity is below $100 \%$, if the relative humidity above $100 \%$ will form liquid water. This condition is based on the optimal values obtained in the research conducted by Mulyazmi et al. (2013). The following is a description of the effect of certain parameters on the formation of the liquid water value and the system voltage of the PEM fuel cell system.

\subsection{Formation of Liquid Water on the Cathode Side with Relative Humidity in the Cathode (Rhc) of $\mathbf{7 5 \%}$}

This phenomenon occurs because the increase in Rha causes the increased water in the vapor phase to move through the MEA together with hydrogen from the anode side to the cathode side by EOD (Mulyazmi et al., 2013). Furthermore, increasing Rhc results in an increase in the amount of water vapor that flows with air into the cathode side. As a result, the amount of liquid water flowing out of the cathode side increases. The same case also occurs with an increase in current density, which results in increased water produced by the reaction within the PEM fuel cell stack. Figure 2 shows that an increase in the Rha value leads to increased system voltage. Optimal system performance occurs at $90 \%$ Rha. Conversely, an increase in the current density value leads to a decrease in PEM fuel cell system performance. The optimal voltage value occurs at a current density of $0.5 \mathrm{~mA} / \mathrm{cm}^{2}$. The value of the PEM fuel cell system voltage causes a very significant decrease in the value of the PEM fuel cell system voltage, occurring at a volume of liquid water above $0.00006 \mathrm{gr} / \mathrm{cm}^{2}$ for condition 1a, above $0.00009 \mathrm{gr} / \mathrm{cm}^{2}$ for condition $2 \mathrm{~b}$, and above 0.0001 $\mathrm{gr} / \mathrm{cm}^{2}$ for condition 2c. PEM fuel cell system performance slightly decreased with lower volumes of liquid water. PEM fuel system performance slightly decreased from 0.66 to 0.63 volts for condition $2 \mathrm{a}$; 0.62 to 0.56 volts for condition $2 \mathrm{~b}$; and 0.59 to 0.53 volts for condition $2 \mathrm{c}$. 


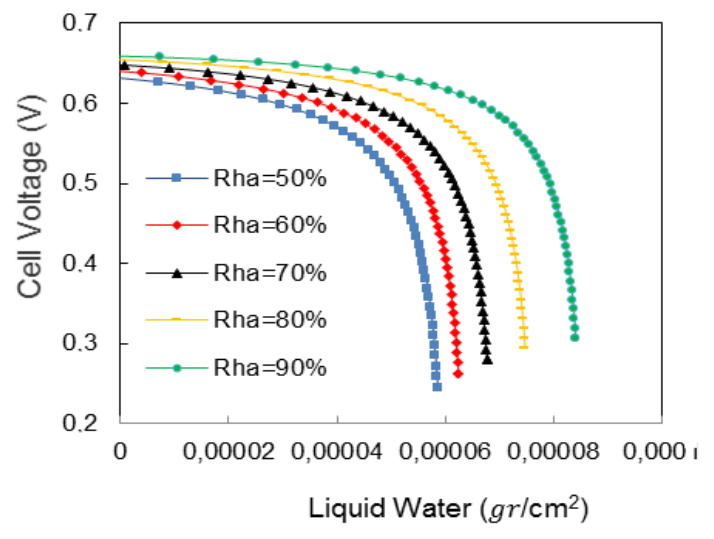

(a)

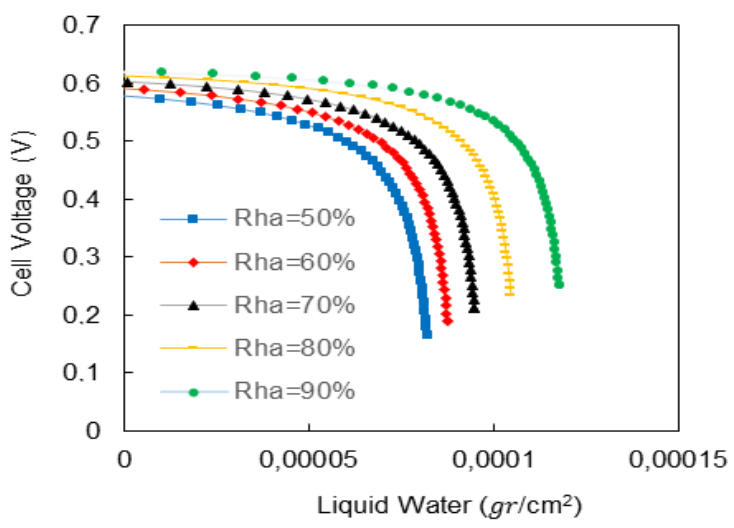

(b)

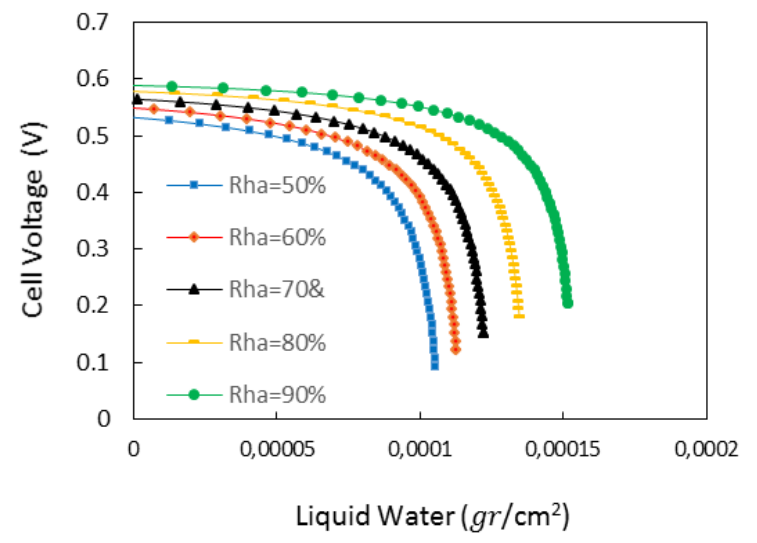

(c)

Figure 2 Effect of liquid water formation on the voltage of a PEM system with an Rhc value of $75 \%$ and different current densities: (a) current density of $0.5 \mathrm{~mA} / \mathrm{cm}^{2}$; (b) current density of 0.7 $\mathrm{mA} / \mathrm{cm}^{2}$; (c) current density of $0.9 \mathrm{~mA} / \mathrm{cm}^{2}$

\subsection{Formation of Liquid Water on the Cathode Side with Relative Humidity in the Cathode (Rhc) of $90 \%$}

Figure 3 shows that the performance of the PEM fuel cell system is relatively more stable in relation to the increase in the amount of liquid water flowing out of the cathode side. Condition $3 \mathrm{a}$ shows that the performance of the system is relatively stable at 0.73 volts to liquid water content of $0.00009 \mathrm{gr} / \mathrm{cm}^{2}$; condition $3 \mathrm{~b}$ at 0.7 volts to liquid water content of $0.00013 \mathrm{gr} / \mathrm{cm}^{2}$; and condition $3 \mathrm{c}$ at 0.67 volts to liquid water content of $0.00016 \mathrm{gr} / \mathrm{cm}^{2}$. Above these operating conditions, the system of PEM fuel cells showed a significant decrease in performance. Based on Figures 2 and 3, optimal system performance is shown in Figure 3c, with Rha and Rhc values of $90 \%$ and current density of $0.9 \mathrm{~mA} / \mathrm{cm}^{2}$. This condition shows that PEM fuel cell performance is relatively stable to 0.67 volts with liquid water content on the cathode side up to $0.00016 \mathrm{gr} / \mathrm{cm}^{2}$. But for PEM fuel cell system application the condition shown by Figure $3 \mathrm{~b}$ can be used. This condition occurs at a value of $90 \%$ Rha and RHc, current density of $0.7 \mathrm{~mA} / \mathrm{cm}^{2}$, and system performance is relatively stable to $0.00013 \mathrm{gr} / \mathrm{cm}^{2}$ liquid water content. 


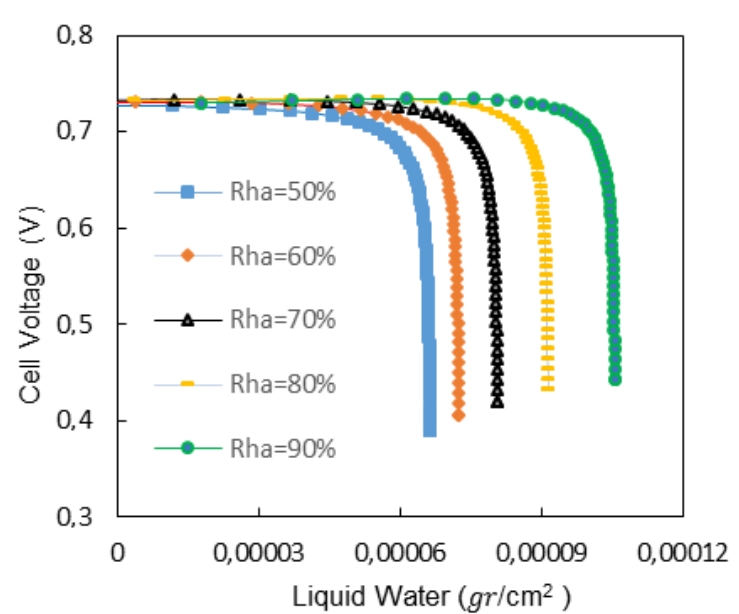

(a)

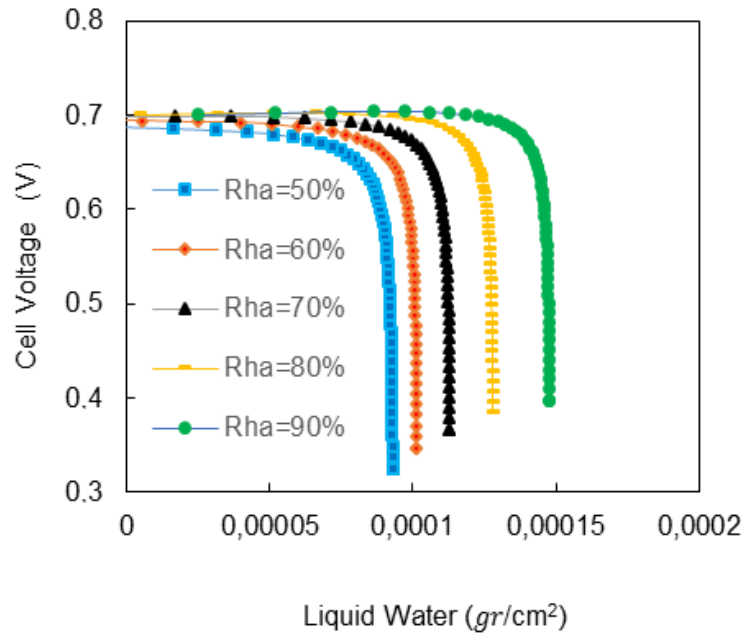

(b)

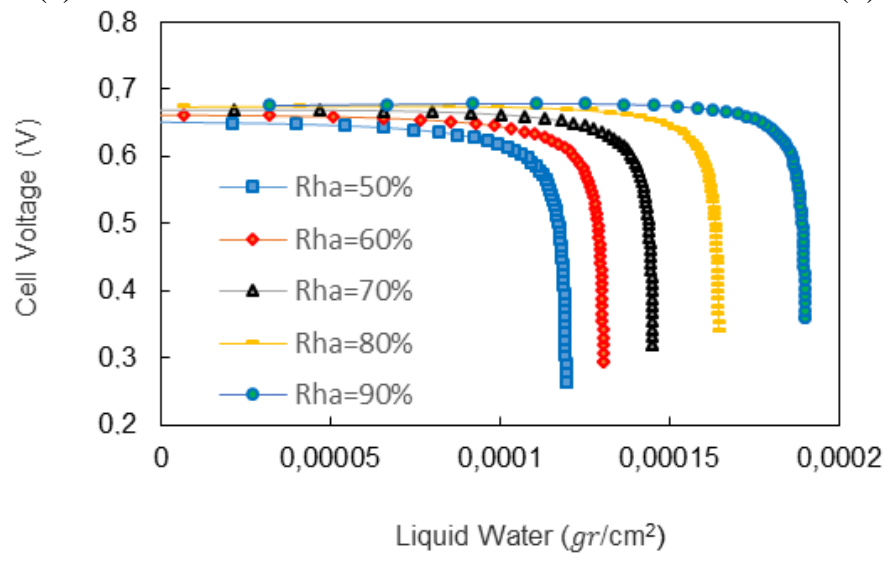

(c)

Figure 3 Effect of liquid water formation on the voltage of a PEM system with an Rhc value of $90 \%$ and different current densities: (a) current density of $0.5 \mathrm{~mA} / \mathrm{cm}^{2}$; (b) current density is 0.7 $\mathrm{mA} / \mathrm{cm}^{2}$; (c) current density of $0.9 \mathrm{~mA} / \mathrm{cm}^{2}$

\subsection{Validation}

This section, the study shows the relationship between the current density of the fuel cell system to the total content of water flowing out from the cathode side. Validation was made by comparing the results of this study with other studies, and simulation was performed by employing modeling using the same parameter conditions as the comparative research, and using Matlab Simulink. Figure 4a show a comparison between the simulation of this study and the research conducted by Cai et al. (2006). Our research shows that the increase in current density results in a total increase in water on the cathode side. The simulation results of this study also produce higher amounts of water compared to the study by Cai et al. (2006), but they show the same trend.

Figure $4 \mathrm{~b}$ shows a comparison of the simulation results with the research by Cai et al. (2006); the two sets of results show the same trend. The amount of water flowing out from the cathode side is slightly different if the current density is below $0.4 \mathrm{~A} \mathrm{~cm}^{-2}$, but if it is above $0.4 \mathrm{~A} \mathrm{~cm}^{-2}$ the amount of water flowing out of the cathode is relatively similar. 


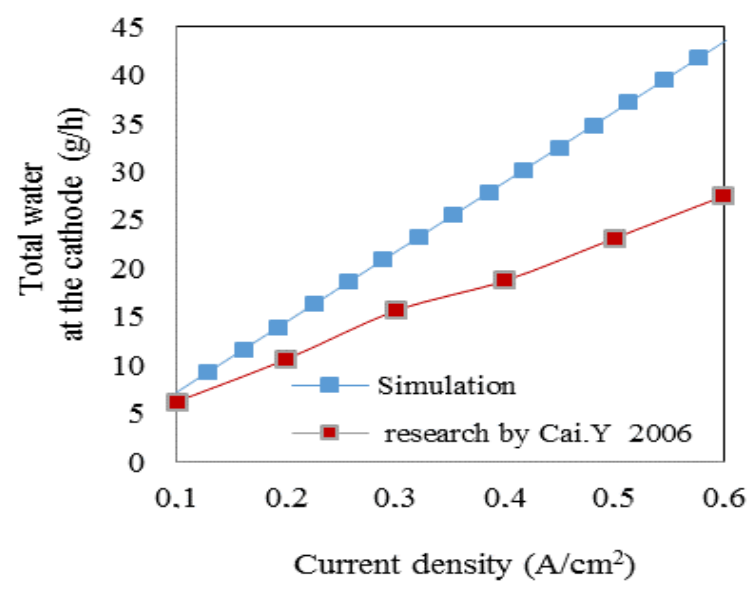

(a)

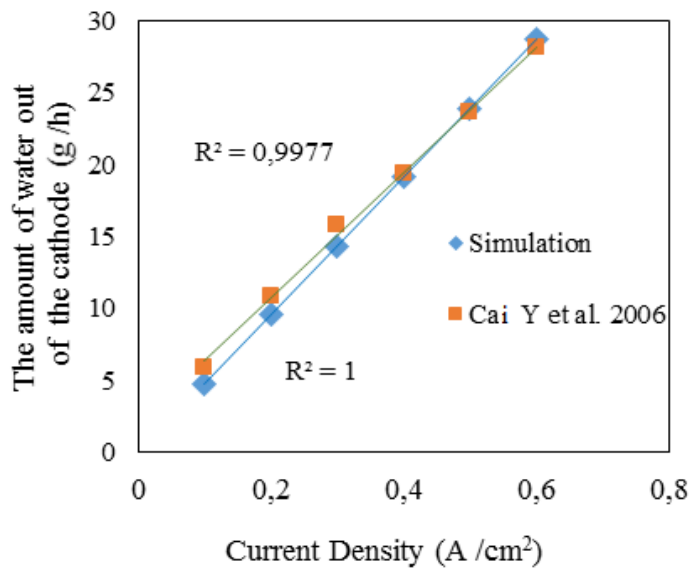

(b)

Figure 4 Simulation results compared with other studies by Cai et al. (2006)

\section{CONCLUSION}

Water management in PEMFC system operation is one of the important factors in avoiding reduced performance and improving cell resilience. This research shows that optimal liquid water content flowing out from the cathode side of the PEM fuel cell system occurs at $90 \%$ Rha and Rhc and with current density at $0.9 \mathrm{~mA} / \mathrm{cm}^{2}$. The performance of the system decreases significantly at $75 \%$ Rhc if the liquid water content flowing out of the side of the cathode is above $0.00013 \mathrm{gr} / \mathrm{cm}^{2}$. Conversely, if the liquid water is below $0.00013 \mathrm{gr} / \mathrm{cm}^{2}$ system performance is relatively stable at 0.7 volts.

\section{ACKNOWLEDGEMENT}

The authors would like to thank the University of Bung Hatta (UBH) and Ministry of Research, Technology and Higher Education of the Republic of Indonesia for supporting the project through a Penelitian Dasar Unggulan Perguruan Tinggi (PDUPT) 2018 research grant Pendidikan Tinggi No: 114/SP2H/LH/DPRM/2018 with contract No. 001/K10/KM/Kontrak-penelitian/2018.

\section{REFERENCES}

Amirinejad, M., Rowshanzamir, S., Eikani, M.H., 2006. Effects of Perating Parameters on Performance of a Proton Exchange Membrane Fuel Cell. Journal of Power Sources, Volume 161(2), pp. 872-875

Cai, Y., Hu, J., Ma, H., Yi, B., Zhang, H., 2006. Effect of Water Transport Properties on a PEM Fuel Cell Operating with Dry Hydrogen. Electrochimica Acta, Volume 51(28), pp. 63616366

Falcão, D.S., Oliveira, V.B., Rangel, C.M., Pinho, C., Pinto, A.M.F.R., 2009. Water Transport through a PEM Fuel Cell: A One-dimensional Model with Heat Transfer Effects. Chemical Engineering Science, Volume 64(9), pp. 2216-2225

Gao, F., Blunier, B., Miraoui, A., El-Moudni, A., 2010. Proton Exchange Membrane Fuel Cell Multi-physical Dynamics and Stack Spatial Non-homogeneity Analyses. Journal of Power Sources, Volume 195(22), pp. 7609-7626

Guvelioglu, G.H., Stenger, H.G., 2007. Flow Rate and Humidification Effects on a PEM Fuel Cell Performance and Operation. Journal of Power Sources, Volume 163(2), pp. 882-891

Hassan, N.S.M., Daud, W.R.W., Sopian, K., Sahari, J., 2009. Water Management in a Single Cell Proton Exchange Membrane Fuel Cells with a Serpentine Flow Field. Journal of Power Sources, Volume 193(1), pp. 249-257 
Kaluža, L., Larsen, M.J., Zdražil, M., Gulková, D., Odgaardb, M., 2015. Fuel Cell Platinum Catalysts Supported on Mediate Surface Area Carbon Black Supports. Chemical Engineering Transactions, Volume 43(6), pp. 913-918

Kraytsberg, A., Ein-Eli, Y., 2006. PEM FC with Improved Water Management. Journal of Power Sources, Volume 160(1), pp.194-201

Li, X., Sabir, I., 2005. Review of Bipolar Plates in PEM Fuel Cells: Flow-field Designs. International Journal of Hydrogen Energy, Volume 30(4), pp. 359-371

Li, Y., Lv, H., 2018. The Combined Effects of Water Transport on Proton Exchange Membrane Fuel Cell Performance. Chemical Engineering Transactions, Volume 65(6), pp. 691-696

Liu, X., Guo, H., Ma, C., 2006a. Water Flooding and Two-phase Flow in Cathode Channels of Proton Exchange Membrane Fuel Cells. Journal of Power Sources, Volume 156(2), pp. 267280

Liu, Z., Mao, Z., Wang, C., 2006b. A Two Dimensional Partial Flooding Model for PEMFC. Journal of Power Sources, Volume 158(2), pp. 1229-1239

Mulyazmi., Daud, W.R.W., Majlan, E.H., M.I. Rosli., 2013. Water Balance for the Design of a PEM Fuel Cell System. International Journal of Hydrogen Energy, Volume 38(22), pp. 9409-9420

Mulyazmi., Ulfah, M., Octavia, S., 2017. Improving the Performance of Single Cells in the Design of Proton Exchange Membrane Fuel Cell (PEMFC) when using Hydrogen. International Journal on Advance Science Engineering Information Technology, Volume 7(2), pp. 53-60

Mulyazmi., Daud, W.R.W., Octavia, S., Ulfah, M., 2018. The Relative Humidity Effect of the Reactants Flows into the Cell to Increase PEM Fuel Cell Performance. MATEC Web of Conferences, Volume 156(7), pp.1-7

Park, Y.H., Caton, J.A., 2008. An Experimental Investigation of Electro-Osmotic Drag Coefficients in a Polymer Electrolyte Membrane Fuel Cell. International Journal of Hydrogen Energy, Volume 33(24), pp. 7513-7520

Rao, R.M., Bhattacharyya, D., Rengaswamy, R., Choudhury, S.R., 2007. A Two-dimensional Steady State Model Including the Effect of Liquid Water for a PEM Fuel Cell Cathode. Journal of Power Sources, Volume 173(1), pp. 375-393

Real, A.J.D., Arce, A., Bordons, C., 2007. Development and Experimental Validation of a PEM Fuel Cell Dynamic Model. Journal of Power Sources, Volume 173(1), pp. 310-324

Spernjak, D., Prasad, A.K., Advani, S.G., 2007. Experimental Investigation of Liquid Water Formation and Transport in a Transparent Single-serpentine PEM Fuel Cell. Journal of Power Sources, Volume 170(2), pp. 334-344

Stumper, J., Löhr, M., Hamada, S., 2005. Diagnostic Tools for Liquid Water in PEM Fuel Cells. Journal of Power Sources, Volume 143(1-2), pp. 150-157

Sun., H., Zhang, G., Guo, L., Dehua, S., Liu, H., 2007. Effects of Humidification Temperatures on Local Current Characteristics in a PEM Fuel Cell. Journal of Power Sources, Volume 168(2), pp. 400-407

Yan, W., Chen, C., Mei, S., Soong, C., Cheng, F., 2006. Effects of Operating Conditions on Cell Performance of PEM Fuel Cells with Conventional or Interdigitated Flow Field. Journal of Power Sources, Volume 162(2), pp. 1157-1164

Yu, X., Zhou, B., Sobiesiak, A., 2005. Water and Thermal Management for Ballard PEM Fuel Cell Stack. Journal of Power Sources, Volume 147(1-2), pp. 184-195

Zhou, B., Huang, W., Zong, Y., Sobiesiak, A., 2006. Water and Pressure Effects on a Single PEM Fuel Cell. Journal of Power Sources, Volume 155(2), pp. 190-202

Zong, Yi., Zhou, B., Sobiesiak, A., 2006. Water and Thermal Management in a Single PEM Fuel Cell with Non-uniform Stack Temperature. Journal of Power Sources, Volume 161(1), pp. 143-159 